\title{
Reinterpretasi Makna Nafkah dalam Bingkai Islam Nusantara
}

\author{
Ahmad Rajafi \\ (Institut Agama Islam Negeri Manado, Jl. Dr. S.H. Sarundajang Kawasan \\ Ringroad I Manado, Email: ahmad.rajafi@gmail.com)
}

\begin{abstract}
Abstrak :
Bagaimanakah Islam Nusantara memandang tentang nafkah dalam keluarga? Inilah pertanyaan yang menjadi landasan berpikir dalam artikel ini. Mengingat bahwa perdebatan tentang nafkah dalam Islam seolah tak kunjung usai, terlebih dengan terus menguatnya pemahaman Islam trans-nasional yang menekankan pentingnya kembali pada al-Qur'an dengan model skriptualistik sehingga ayat tentang nafkah digunakan sebagai pembenaran terhadap kuasa lakilaki atas perempuan. Disinilah pentingnya untuk memaknai kembali konsep nafkah dengan pendekatan Islam Nusantara melalui model teori inkulturasi wahyu dan budaya lokal, sehingga lahir produk hukum yang responsif dan shâlih li kulli zamân wa makân. Hasilnya adalah, konsep nafkah harus dimaknai sebagai kemufakatan ekonomi dalam keluarga, di mana pembacaan ayat tentang nafkah di dalam alQur'an harus dikaitkan dengan sejarah awal Islam yang memperlakukan wanita secara minor menuju perlakuan major, sehingga wanita (istri) yang dulunya seolah-olah dilarang dalam mencari nafkah dapat bertransformasi untuk ikut serta dalam membangun ekonomi keluarga atau bahkan sebagai pencari nafkah utama dalam rumah tangga yang bertukar tempat dengan suaminya.
\end{abstract}

Kata Kunci:

Wahyu, Budaya Lokal, Nafkah, Islam Nusantara

\begin{abstract}
:
How does Islam Nusantara consider a living in the family? In this article, this question becomes the foundation of thinking. As we know, debating of a living family in Islam seems to be endless, especially with the continued strengthening of trans-national Islamic understanding which emphasizes the importance of returning to the Qur'an with a scripturalistic model so that the verse on living is used as a justification against the power of men over women. This is the importance to redefine a concept of a living in a family with the
\end{abstract}




\section{Ahmad Rajafi}

approach of Islamic Nusantara through the model of inculturation theory of revelation and local culture, so that created the responsive law products and shâlih li kulli zamân wa makân. The result is that the concept of living must be interpreted as the economic agreement in the family, where the reading of the verses about living in the Qur'an must be linked to the early history of Islam which treats women in a minor way toward the major treatment, so that the woman (wife) as if prohibited in earning a living can be transformed to participate in developing the family economy or even as the main breadwinner in the households that exchange places with her husband.

\section{Keywords:}

Revelation, Local Culture, Nafkah, Islam Nusantara

\section{Pendahuluan}

Nafkah dalam pandangan umum umat Islam adalah kewajiban laki-laki (suami) dan dirasa tabu jika perempuan (istri) turut serta mencari nafkah keluarga, sehingga terbangun image bahwa perempuan hanya memiliki tugas domestik dan laki-laki pada tugas publik. Hal ini didasarkan atas firman Allah SWT Q.S. al-Nisâ' 4: $34 .{ }^{1}$

"Kaum laki-laki itu adalah pemimpin bagi kaum wanita, oleh karena Allah telah melebihkan sebahagian mereka (laki-laki) atas sebahagian yang lain (wanita), dan karena mereka (laki-laki) telah menafkahkan sebagian dari harta mereka..."

Terjemahan di atas merupakan terjemahan yang umum diketahui dan dipahami oleh masyarakat, di mana laki-laki adalah "pemimpin" bagi perempuan. Kementerian Agama RI pada tahun 2012 telah melakukan revisi atas penerjemahan di atas, di mana dalam terjemahan baru tersebut, kata qawwâm tidak lagi diartikan sebagai "pemimpin", akan tetapi sebagai "pelindung". Sehingga dalam

\footnotetext{
${ }^{1}$ Muhammad Ali al-Shabuni, Rawâ'i' al-Bayân Tafsîr Âyât al-Ahkâm min al-Qur'ân, Alih Bahasa oleh Ahmad Dzulfikar, at.al., Tafsir Ayat-Ayat Ahkam, (Depok: Keira Publishing, 2016), I, . 477.
} 
terjemahan 2012 disebutkan; "laki-laki (suami) itu pelindung bagi perempuan (istri)."2

Karena ayat tersebut secara khusus menjelaskan tentang peraturan hidup suami istri, maka konsekuensi dari itu semua adalah lahir sebuah tanggungjawab dari seorang pelindung untuk melindungi apa dan siapa saja yang ia lindungi, termasuk dengan kewajiban memberi nafkah (wa bimâ anfaqû min amwâlihim). Untuk itu dalam tafsir Kementerian Agama RI ditegaskan, apabila suami tidak memenuhi kewajiban dan tanggungjawabnya, maka istri berhak mengadukannya kepada hakim yang berwenang menyelesaikan maslahanya. ${ }^{3}$

Abd al-Rahmân al-Sa'dî̀ menafsirkan kalimat "wa bimâ anfaqû min amwâlihim" sebagai sebuah petunjuk pengutamaan laki-laki atas wanita karena sebab kewajiban memberi nafkah kepada istri, dan laki-laki merupakan wali dan tuan bagi istrinya, sedangkan istri adalah pendamping, tawanan dan pelayan, untuk itu maka tugas laki-laki harus menunaikan perintah Allah SWT tersebut yakni memberi perlindungan dan nafkah.

Al-Qurthubî $\hat{1}^{5}$ memberi penekanan tentang pentingnya pemberian nafkah seorang suami kepada istri dengan menunjukkan sebab turunnya ayat tersebut sebagai sebuah jawaban atas pernyataan Ummu Salamah yang mempertanyakan kelebihan laki-laki di dalam pembagian harta waris dibandingkan dengan bagian wanita, lalu Allah SWT memberi penjelasan tentang keutamaan laki-laki di dalam pembagian harta waris karena adanya kewajiban dari setiap laki-laki untuk mengeluarkan mahar dalam perkawinan dan infak dalam keluarga melalui kalimat "wa bimâ anfaqû min amwâlihim".

Adapun Quraish Shihab menjelaskan, bahwa unit terkecil dari keluarga adalah suami dan istri, atau ayah, ibu, dan anak, yang bernaung di bawah satu rumah tangga. Unit ini memerlukan

\footnotetext{
2 Kementerian Agama RI, Al-Qur'an dan Tafsirnya (Jakarta: Direktorat Jenderal Bimbingan Masyarakat Islam Direktorat Urusan Agama Islam, 2012), II, 161.

${ }^{3}$ Ibid., 162.

4 Abd al-Rahmân bin Nâshir al-Sa'dî, Taisîr al-Karîm al-Rahmân fi Tafsîr Kalâm alMannân, Alih Bahasa oleh Muhammad Iqbal, at.al., Tafsir Al-Qur'an Surat An-Nisâ' Al-An'am, Cet. 6 (Jakarta: Darul Haq, 2015), II, 70.

${ }^{5}$ Abû Abdillâh Muhammad bin Ahmad al-Anshârî al-Qurthûbî, al-Jâmi' li Ahkâm alQur'ân (Kairo: Dâr al-Hadîts, 2002), III, 153.
} 
pemimpin, dan dalam pandangan al-Qur'an yang wajar memimpin adalah bapak, alasannya pertama Karena Allah melebihkan sebagian mereka atas sebagian yang lain, dan kedua Karena mereka (para suami diwajibkan) untuk menafkahkan sebagian dari harta mereka (untuk istri/keluarganya). ${ }^{6}$

Melalui penjelasan Allah tentang nafkah tersebut, maka imamimam madzhab memberi penegasan kembali tentang pentingnya pemberian nafkah dari seorang suami kepada istrinya, bahkan dengan istilah "hak" bagi istri. Al-Syâfi'î dalam qaul qadîm-nya dan Abû Hanifah serta Ibnu Hazm dari kalangan Zhâhiriyyah berpendapat bahwa hak nafkah terhadap istri terjadi tatkala terlaksananya akad. Adapun al-Syâfi'î dalam qaul jadîd-nya lalu Mâlikiyyah dan Hanâbilah mengungkapkan bahwa istri baru mendapatkan hak nafkah dari suaminya adalah ketika ia sudah tinggal satu atap dengan suaminya (tamkîn). Sementara itu menurut pendapat mutakhirîn, istri baru mendapatkan hak nafkah setelah ia pindah ke rumah suaminya. ${ }^{7}$

Penjelasan para ulama tersebut kini menjadi pegangan mainstream umat Islam sehingga menganggap hal yang tidak wajar jika ada istri yang memberi nafkah. Bahkan dalam sebuah sinetron religi yang ditayangkan pada bulan Ramadhan yang lalu (Juni 2017) digambarkan aktivitas sosial di mana istri-istri mencari uang sebagai Tenaga Kerja Wanita (TKW) ke luar negeri dan suami-suami menjadi pengelola uang nafkah dari istri dan mengurus anak-anak serta kebutuhan rumah tangga, dengan judul "Dunia Terbalik".

Stigma negative tersebut ternyata tidak berbanding lurus dengan fakta sosial, baik di perkotaan maupun di pedesaan yang menggambarkan aktivitas ekonomi keluarga yang tidak hanya bersumber dari suami tapi juga dari istri, bahkan ada yang hanya dari satu pintu saja yakni istri. Inilah praktik sosial di Indonesia, yang didominasi oleh umat Islam, umat mayoritas dan terbesar di dunia, di mana perempuan memiliki hak yang sama pada ranah publik untuk turut serta mensejahterakan dan memajukan ekonomi keluarga.

${ }^{6}$ M. Quraish Shihab, Wawasan Al-Qur'an: Tafsir Maudhu'i atas Pelbagai Persoalan Umat (Bandung: Mizan, 1996), 209.

${ }^{7}$ Lihat Wahbah al-Zuhailî, al-Figh al-Islâmî wa Adillatuh (Suriah: Dâr al-Fikr, 2002), X, 7374-7375. 
Kreativitas perempuan pada ranah publik tersebut telah berlangsung sebelum Islam datang dan menjalin harmoni dengan wahyu yang disampaikan oleh para $d u^{\prime} a ̂ t$ (pendakwah) ketika menyebarkan Islam. Harmonisasi wahyu dan budaya lokal tersebut kini seloah digugat oleh para pendakwah Islam transnasional, dengan dalil-dalil agama (al-Qur'an dan al-Hadits) mereka kembali mensubordinasi perempuan sebagaimana perilaku masyarakat Arab jahiliyah pra-Islam.

Berdasarkan masalah sosial-keagamaan tersebut maka lahirlah beberapa kajian-kajian ilmiah yang secara spesifik menjelaskan tentang nafkah dari berbagai perspektif, namun progresifitas berpikir yang menempatkan pasangan dalam kerangka "persamaan" seolah belum mendapat tempat, terlebih lagi jika diarahkan pada ranah hukum responsif dengan locus utama yakni Islam Nusantara. Sebagai contoh adalah artikel yang ditulis oleh Hirul Hudaya tentang Hak Nafkah Isteri (Perspektif Hadis dan Kompilasi Hukum Islam). ${ }^{8}$ Pada artikel tersebut ditunjukkan sisi kesamaan dan perbedaan produk hukum yang lahir dari hadits dan dari KHI, namun progresifitas hukum Islam belum ditunjukkan sehingga apakah produk hukum dari KHI tersebut responsif bagi umat Islam di Indonesia atau tidak. Inilah salah satu titik distingsi artikel ini dengan yang lainnya, di mana pembacaan atas progresifitas hukum Islam melalui nalar Islam Nusantara secara komprehensif akan diketengahkan.

\section{Memaknai Kata Nafkah}

Kata nafkah diserap ke dalam bahasa Indonesia dari bahasa arab yakni an-nafaqah yang berasal dari suku kata anfaqa-yunfiquinfaqan (انفق-ينفق-انفاقا) yang berarti yang berarti al-mashrûf wa alinfâq, yakni biaya belanja, pengeluaran uang, dan biaya hidup. ${ }^{10}$ Pendapat lain menyatakan bahwa nafkah berasal dari bentuk kata dasar/kata benda (masdar/noun) dari kata kerja "nafaqa" yang sering disepadankan pengertiannya dengan kata kerja dzahaba, kharaja, nafada

\footnotetext{
8 Lihat Hairul Hudaya, "Hak Nafkah Isteri (Perspektif Hadis dan Kompilasi Hukum Islam)", Mu'adalah Jurnal Studi Gender dan Anak, 1 \& 1 (2013), 25-35.

${ }_{9}^{9}$ Louis Ma'luf al-Yasu'i, al-Munjid (Beirut: al-Syirkiyah, 1986), 828.

${ }^{10}$ Ahmad Warson Munawwir, Al-Munawwir Kamus Arab-Indonesia (Yogyakarta: Pondok Pesantren Al-Munawwir, 1984), 1449.
} 
dan madhâ (ذهب، خرج، نفد، مضى)11, maksudnya adalah bahwa katakata tersebut memiliki kesamaan dalam segi pengertiannya, yaitu sama-sama menunjukkan keberpindahan suatu hal ke hal yang lain. Kata madha yang berarti berlalu atau lewat dan dzahaba yang berarti pergi, serta kharaja yang berarti keluar, sama-sama menunjuk pengertian perpindahan dari satu tempat/situasi ke tempat/situasi yang lain. Kata nafida yang berarti habis, juga menunjuk perpindahan dan perubahan sesuatu dari yang semula ada menjadi tidak ada. ${ }^{12}$

Adapun kata al-nafaqah (dalam bentuk muta'addi anfaqa) secara etimologis juga berarti perbuatan memindahkan dan mengalihkan sesuatu. Sebagai bentuk kata benda, maka nafkah memiliki arti sesuatu yang dipindahkan atau dialihkan dan dikeluarkan untuk suatu hal dan tujuan tertentu, dan kata tersebut digunakan untuk pengertian positif. ${ }^{13}$ Adapun di dalam Kamus bahasa Indonesia, kata nafkah diartikan sebagai belanja untuk hidup; (uang) pendapatan; belanja yg diberikan kepada istri; rezeki; bekal hidup sehari-hari. ${ }^{14}$ Adapun bila kata nafkah dihubungkan dengan perkawinan, maka ia dapat berarti sesuatu yang dikeluarkannya dari hartanya untuk kepentingan istrinya sehingga menyebabkan hartanya menjadi berkurang. 15

Menurut terminologi fiqh, para ahli fiqh (fuqahâ') mendefinisikannya sebagai biaya yang wajib dikeluarkan oleh seseorang terhadap sesuatu yang berada dalam tanggungannya meliputi biaya untuk kebutuhan pangan, sandang, papan, termasuk juga kebutuhan sekunder seperti perabot rumahtangga. ${ }^{16}$ Adapula yang secara khusus membatasi pengertian nafkah hanya pada tiga aspek pokok saja, yakni pangan (math'âm), sandang (malbâs), dan

\footnotetext{
${ }^{11} \mathrm{Abd}$ al-Rahmân al-Jazirî, al-Fiqh 'alâ al-Madzâhib al-Arba'ah (Beirut: Dar al Fikr, tt), IV, 260. Bandingkan juga dengan Abû al-Qâsim al-Husain bin Muhammad, alMufradat fi Gharîb al-Qur'an (Beirut: Dar al-Fikr, t.th.) 502.

12 Nurnazli, "Nafkah dalam Pendekatan Interdisipliner", Asas Jurnal Hukum dan Ekonomi Islam, 5 \& 2 (2013), 2

13 Abû Bakr bin Sayyid Muhammad Syathâ Dimyathî, I'ânah al-Thâlibîn (Beirût: Dâr al-Fikr, t.t.), IV, 60.

14 Pusat Bahasa, Kamus Bahasa Indonesia (Jakarta: Departemen Pendidikan Nasional, 2008), 992.

15 Amir Syarifuddin, Hukum Perkawinan Islam di Indonesia: Antara Fiqh Munakahat dan Undang-undang Perkawinan, Cet. II, (Jakarta: Kencana, 2007), 165

16 al-Jazirî, al-Fiqh 'alâ al-Madzâhib al-'Arba'ah (Beirût: Dâr al-Fikr, 1996), IV, 260.
} 
papan (maskân), ${ }^{17}$ bahkan ada yang lebih sempit lagi memaknainya khusus pada math'am saja. Adapun Abd al-Wahab Khalaf secara tegas di dalam bukunya menyebutkan istilah nafkah untuk istri (nafaqah azzaujah) bukan nafkah saja, yang didefiniskan olehnya:

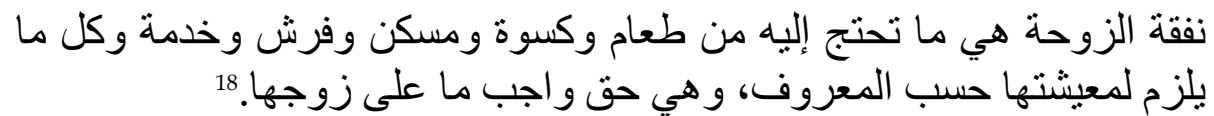

"Nafkah kepada istri adalah, kebutuhan berupa makanan, pakaian, tempat tinggal, tempat tidur, pelayanan, dan segala sesuatu yang menyangkut kebutuhan hidupnya secara baik, dan hal tersebut merupakan hak yang wajib dikeluarkan oleh suaminya."

Definisi yang lebih umum lagi dirumuskan oleh Sâlim bin Abd al-Ghanî ar-Râfi'î dengan menyebutkan bahwa istri yang berhak mendapat nafkah bukan saja yang berstatus muslimah, akan tetapi istri dari kalangan ahl al-kitâb pun berhak untuk mendapatkan nafkah tersebut, sebagaimana penjelasannya:

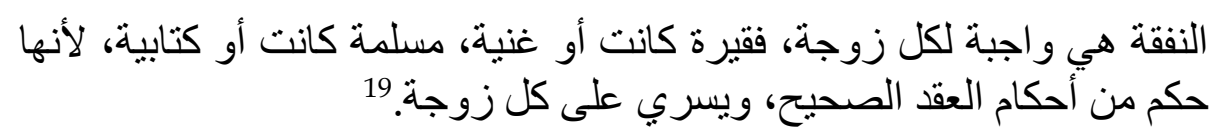
"Nafkah adalah sesuatu yang wajib diterima oleh istri, baik ia tergolong miskin ataupun kaya, muslimah ataupun ahli kitab, karena nafkah tersebut dikategorikan sebagai bagian dari hukum perikatan yang benar, dan berlaku kepada setiap istri."

Secara prinsip, nafkah lahir karena adanya beban tanggungjawab (dzimmah), sehingga karakteristiknya sama dengan ketentuan kafarat yang menjadi sebuah kewajiban sebagai akibat dari beban pertanggungjawaban atas sebuah perbuatan. Selain kesamaan tersebut, ketentuan nafkah juga memiliki takaran besaran kewajiban yang disesuaikan dengan kemampuan pihak yang akan memberi nafkah, sebagaimana kafarat yang menentukan pula tingkatan besaran kewajiban dengan disesuaikan atas perbuatan berdasarkan penyebabnya. ${ }^{20}$

\footnotetext{
17 Al-Hashfakî, al-Dur al-Mukhtâr (Beirût: Dâr al-Fikr, 1386 H), III, 572.

18 Abd al-Wahâb Khalâf, Ahkâm al-Ahwâl al-Syakhshiyyah fî al-Syarî'ah al-Islâmiyyah, cet. 2 (Kuwait: Dâr al-Qalam, 1990), 104.

19 Sâlim bin Abd al-Ghanî al-Râfi'î, Ahkâm al-Ahwâl al-Syakhshiyyah li al-Muslimîn fi alGharb (Beirût: Dâr Ibn Hazm, 2002), 476.

${ }^{20}$ Zakariyyâ al-Anshârî, Fath al-Wahhâb (Beirût: Dâr al-Kutub al-'Ilmiyyah, 1418 H), II, 200.
} 
Berdasarkan definisi-definisi nafkah tersebut beserta karakteristiknya, maka secara operasional, kata nafkah dapat dirumuskan dalam pengertian kewajiban seseorang yang timbul sebagai akibat perbuatannya yang mengandung beban tanggungjawab, berupa pembayaran sejumlah biaya guna memenuhi kebutuhan primer, sekunder maupun tersier dari sesuatu yang menjadi tanggungannya. Adapun mengenai kadar nafkah, Khoiruddin Nasution tidak mendapatkan ketetapannya secara pasti dalam dalil-dalil naqlî, hanya saja perlu disesuaikan kadar sandang dan pangan yang wajib ditunaikan tersebut berdasarkan kemampuan. ${ }^{21}$ Sedangkan Syamsul Bahri memberi penegasan bahwa kadar nafkah yang paling baik diberikan oleh suami kepada isteri sebagaimana yang dijelaskan dalam al-Qur'an, yaitu harus melihat kedudukan sosial dan tingkat kemampuan suami isteri. Jadi tidak berlebih-lebihan sehingga memberatkan suami dan juga tidak telalu sedikit, akan tetapi sesuai dengan kemampuan suami. ${ }^{22}$

Pendapat yang cukup menarik adalah dari kalangan Hanabilah, sebagaimana yang dikutip oleh Ibnu Rozali, di mana kadar nafkah diukur sesuai dengan kondisi suami-isteri. Jika keduanya termasuk golongan yang dimudahkan rejekinya oleh Allah (artinya sama-sama berasal dari keluarga berada), maka wajib bagi suami memberi nafkah dengan kadar yang sesuai dengan keadaan keluarga mereka berdua. Jika keduanya berasal dari keluarga miskin, maka kewajiban suami memberi nafkah sesuai dengan keadaan mereka. Namun, jika keduanya berasal dari keluarga yang berbeda tingkat ekonominya, maka kewajiban suami adalah memberikan nafkah sesuai dengan kadar keluarga kalangan menengah. ${ }^{23}$

\section{Pembacaan Progresif dan Responsif Tentang Dalil Nafkah}

Keluarga Arab kuno (pra-Islam) adalah model keluarga patriakhi, di mana bapak adalah poros tali kekerabatan di dalam

${ }^{21}$ Khoiruddin Nasution, Islam Tentang Relasi Suami dan Istri (Hukum Perkawinan I) Dilengkapi Perbandingan Undang-undang Negara Muslim (Yogyakarta: Tazzafa Academia, 2004), 181.

22 Syamsul Bahri, "Konsep Nafkah dalam Hukum Islam", Kanun Jurnal Ilmu Hukum, 66 \& 18 (2015), 397.

${ }^{23}$ Ibnu Rozali, "Konsep Memberi Nafkah Bagi Keluarga dalam Islam", Intelektualita, 6 \& 2 (2017), 199. 
keluarga dengan seluruh anak keturunannya mengikuti garis kekerabatan ayah dan keluarga ayahnya tersebut, sedangkan ibu dan seluruh garis kekerabatannya dianggap bagian eksternal atau bukan dari bagian keluarga yang mengikat baginya.24 Budaya pra-Islam tersebut menegaskan tentang kewenangan penafkahan keluarga yang berada pada kuasa laki-laki (bapak), dan ketika Islam datang kewenangan tersebut diakomodasi di dalam Islam sebagaimana tertuang di dalam Q.S. al-Nisâ' 4:34. Ayat lainnya yang juga menjelaskan tentang nafkah adalah Q.S. al-Thalâq 65: 7:

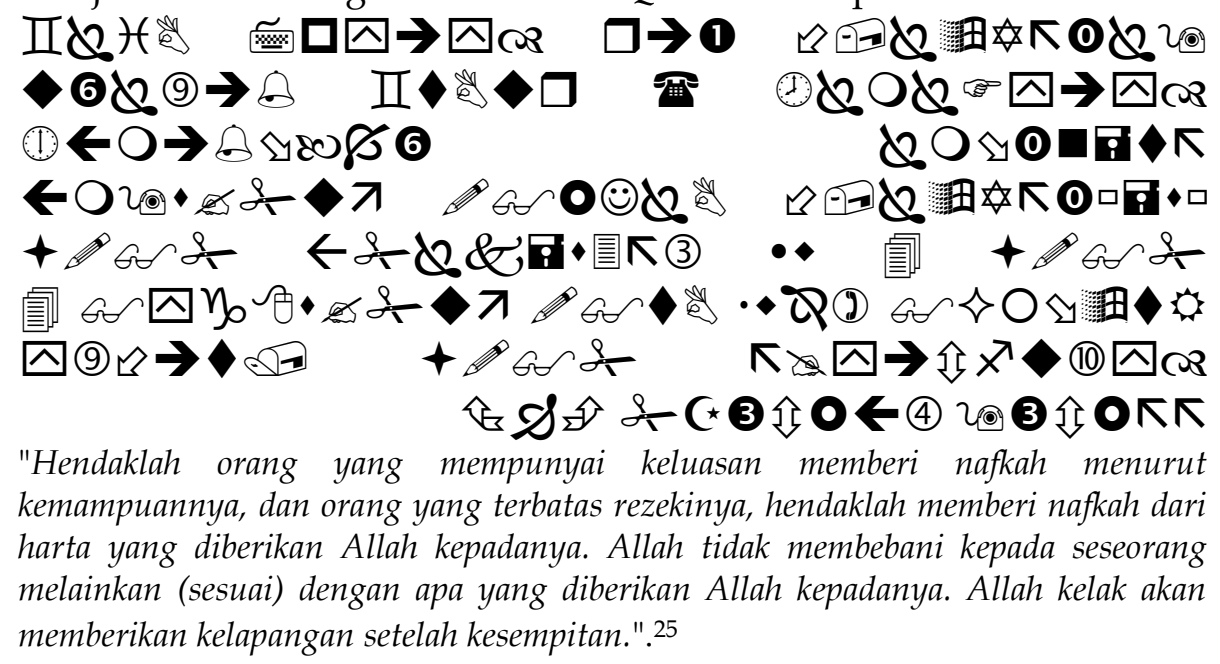

Menurut Jumni Nelli, ayat di atas tidak memberikan ketentuan yang jelas dan pasti mengenai berapa besarnya ukuran nafkah seorang suami kepada isteri baik berupa batas maksimal maupun batas minimal. Tidak adanya ketentuan yang menjelaskan berapa ukuran nafkah secara pasti, justru menunjukkan betapa fleksibelnya Islam dalam menetapkan aturan nafkah. ${ }^{26}$ Rasûlullâh Muhammad saw juga bersabda:

24 Ahmad Rajafi dan Rahmat Yudistiawan, "Kewarisan Produktif: Meramu Makna Adil Melalui Waris Produktif", Al-Risalah: Forum Kajian Hukum dan Sosial Kemasyarakatan, 16 \& 2 (2016), 308.

25 Kementerian Agama RI, Al-Qur'an..., 188-189.

26 Jumni Nelli, "Analisis Tentang Kewajiban Nafkah Keluarga dalam Pemberlakuan Harta Bersama", Al Istinbath: Jurnal Hukum Islam, 2 \& 1 (2017), 32 


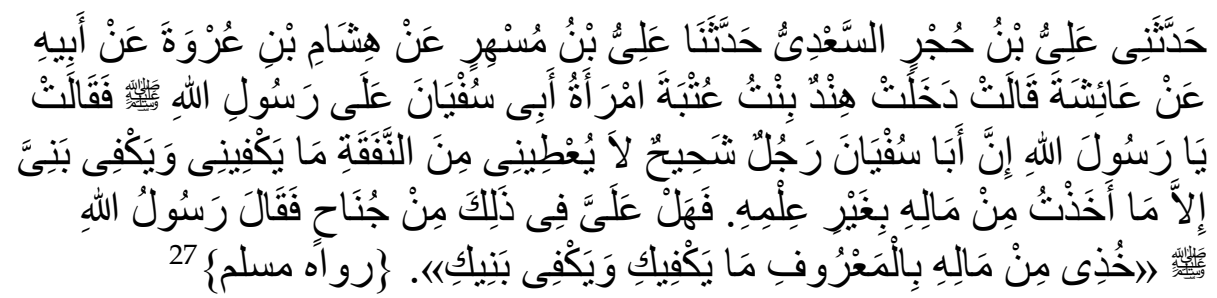

"Alî bin Hujr as-Sa'dî menyampaikan kepadaku, Alî bin Mushir menyampaikan kepada kami dari Hisyâm bin 'Urwah dari ayahnya dari Âisyah, ia berkata; Hindun binti Utbah istri dari Abû Sufyân mendatangi Rasûlullâh saw serya berkata; wahai Rasûlullâh, sesungguhnya Ab̂̂ Sufyân adalah orang yang kikir, ia tidak memberiku nafkah untuk kebutuhanku dan anakku, selain apa yang telah aku ambil sendiri dari hartanya tanpa diketahui olehnya, maka apakah saya berdosa atas perbuatan tersebut, maka Rasûlullâh saw bersabda; ambillah dari hartanya secara baik-baik untuk kebutuhanmu dan anakmu." (HR. Muslim).

Atas dasar dalil-dalil agama tersebut, ulama merumuskan kewajiban nafkah pada beberapa klasifikasi:

1. Zaujiyyah (Ikatan Pernikahan): Pemberian nafkah karena ikatan pernikahan yang sah ini bukan saja terjadi dalam pernikahan yang utuh, akan tetapi juga pada pernikahan yang telah putus dalam talak raj'î dan talak $b \hat{a}^{\prime}$ in hamil. Namun menurut kalangan Mâlikiyyah dan Syâfi'iyyah, untuk talak bâ'in hamil, bentuk nafkah hanya berupa tempat tinggal saja. ${ }^{28}$

2. Qarabah (Hubungan Kerabat): Kalangan Mâlikiyyah berpendapat bahwa kerabat yang berhak mendapatkan nafkah hanya pada hubungan orangtua dan anak (al-wâlid wa al-walad). Syâfi'iyyah berpendapat bahwa nafkah diberikan kepada hubungan orang tua dan anak serta cucu dan kakek (ushîl dan furû'). Adapun Hanâfiyyah berpendapat, yang mendapat nafkah karena kerabat bukan saja ushûl dan furû' akan tetapi juga pada jalur ke samping (hawâsyi) dan dzawi al-arhâm. Sedangkan Hanâbilah berpendapat lebih umum lagi asalkan pada jalur nasab.29

3. Milk (Kepemilikan Terhadap Budak): Pada bagian ini, pembacaan kekinian dibutuhkan dalam memaknai kata kepemilikan (al-milk) tersebut. Karena status budak saat ini sudah tidak lagi

27 Abû al-Husein Muslim bin al-Hajjâj bin Muslim al-Qusyairî al-Nisâbûrî, al-Jâmi' alShahîh al-Musammâ Shahîh Muslim (Beirût: Dâr al-Afâq al-Jadîdah, t.t.), V, 129.

28 Zuhailî, al-Fiqh..., 105; al-Jaziri, al-Fiqh..., 240.

29 Zuhailî, al-Fiqh..., 84-85. 
digunakan, maka arah pemaknaan kerabat pada konteks kepemilikian dapat diarahkan pada hal-hal yang berada dalam perlindungannya, seperti asisten rumahtangga, hewan atau tumbuhan yang dipelihara, anak-anak yatim yang berada dalam tanggungannya, dan lain-lain.

Berdasarkan semua keterangan tersebut, ulama bersepakat untuk menempatkan suami sebagai pihak yang dibebankan kewajiban nafkah kepada istri dan anak-anaknya. ${ }^{30}$ Ismâ'îl Haqqî menegaskan bahwa secara eksplisit, kemutlakan kewajiban nafkah dibebankan kepada suami dipahami dari petunjuk dalam QS. anNisâ' ayat 34, yang menginformasikan keistimewaan laki-laki dibandingkan wanita disebabkan salah satu faktornya adalah nafkah. ${ }^{31}$

Keputusan tersebut lahir dari para ulama karena hukum asal kewajiban laki-laki atas nafkah berawal dari konteks hubungan akad nikah yang menempatkan perempuan sebagai objek (muqtadla al-'aqd; tuntutan yang terdapat dalam akad). Oleh karena itu, akad nikah seolah menjadi ruang yang mana perempuan tertanggung (ihtibas) kehidupannya di dalam ruang itu. Maka suami menjadi aktor paling penting tentang kepemilikan terhadap ruang gerak isterinya, sehingga suami secara utuh berkewajiban untuk memberi nafkah. ${ }^{32}$ Bahkan demi menguatkan pemahaman tersebut, mayoritas ulama lalu menyepakati bahwa:

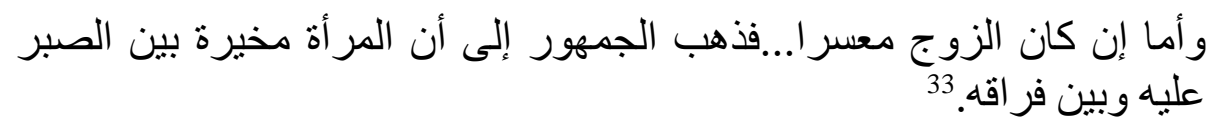

"Adapun jika suami itu tidak mampu (susah)...maka jumhur ulama berpendapat bahwa bagi wanita (istri) tersebut memiliki pilihan untuk bersabar bersama suaminya atau meminta cerai dengannya."

Pendapat yang dikeluarkan oleh jumhur tersebut tidak bersifat solutif, karena istri seolah tidak memiliki peran yang setara

\footnotetext{
30 Sayyid Sâbiq, Fiqh al-Sunnah (Kairo: Dâr al-Fikr, 2002), II, 169-170.

${ }^{31}$ Ismâ'îl Haqqî, Tafsir Rûh al-Bayân (Beirût: Dâr Ihyâ' at-Turâts al-'Arabi, t.t.), II, 160.

32 Subaidi, "Konsep Nafkah Menurut Hukum Perkawinan Islam", Isti'dal: Jurnal Studi

Hukum Islam, 1 \& 2 (2014), 160

33 ar-Râfi'î, Ahkâm..., 479.
} 
dalam keluarganya, sifatnya pasif dan bahkan terindikasi "menjadi beban" dalam keluarga, padahal peran istri bisa lebih dari itu, termasuk dalam pembangunan ekonomi keluarga. Terlebih lagi, menurut temuan terbaru oleh Tim peneliti dari University of Pennsylvania, Amerika Serikat, menunjukkan bukti mengejutkan bahwa otak laki-laki dan perempuan memiliki fungsi yang berbeda. Seperti yang dilansir Daily Mail (3 Desember 2013), Tim peneliti menemukan otak perempuan terprogram untuk melakukan multitasking atau banyak pekerjaan, sementara otak laki-laki lebih baik menjalankan tugas tunggal. ${ }^{34}$

Temuan tersebut mempertegas bahwa kemampuan perempuan melakukan banyak pekerjaan yang ditopang oleh struktur otaknya tersebut sesungguhnya melengkapi sisi lain kekuatan fisik perempuan sebagai makhluk yang memiliki tingkat keunggulan yang tidak kalah dari laki-laki. ${ }^{35}$ Oleh karenanya, untuk mendapatkan jawaban hukum yang progresif namun tetap responsif dan ramah gender atas problem laki-laki dan perempuan dalam konteks nafkah, maka perlu didialogkan kembali dalil-dalil tersebut dalam sejarah dan budaya yang hidup ketika dalil tersebut lahir dengan konteks saat ini dan budaya Nusantara sebagai locus-nya.

Pembacaan yang mendalam terhadap wahyu Allah menuju interpretasi yang progresif dan responsif bukanlah perkara sederhana, tetapi merupakan aktifitas kompleks yang melibatkan potensi fisik dan mental (ijtihad). Dalam aktifitas ini sangat mungkin terjadi kesalahan dalam menafsirkan. Adanya perbedaan bahasa yang digunakan pada setiap masyarakat, keikutsertaan emosional yang menyertai ungkapan dalam sebuah bahasa, juga merupakan kendala penafsiran, sebab ungkapan yang sama bentuknya, bisa berbeda maksudnya. Meskipun demikian, bukan berarti dengan alasan tersebut lalu bersikap skeptis untuk melakukan pembacaan baru atas norma yang sudah belaku sebelumnya, akan tetapi seharusnya dengan alasan tersebut semakin melahirkan hasrat yang kuat (ghîrah) untuk dapat menemukan formulasi jawaban hukum baru dan terbarukan dari sebuah norma agama (nash).

\footnotetext{
34 Lihat Nunu Burhanuddin, "Membincang Persepsi Keterpinggiran Perempuan", Esensia: Jurnal Ilmu-Ilmu Ushuluddin, 16 \& 1 (2015), 61

35 Ibid. 
Dialog atau komunikasi vertikal, hanya mampu dilakukan dengan jalan inkulturasi antara wahyu dan budaya lokal yang hidup di dalam masyarakat, serta menafikan kehendak taklid yang bersifat qaulî namun tidak menafikan manhajî-nya, sebagaimana penjelasan Nashr Hamid Abu Zaid yang mempertanyakan sisi esensial dari hukum Islam, yakni "apakah mereka yang hanya mereproduksi turats dengan mekanisme meringkas dan merangkum berdasarkan komentar-komentar, bukan sumber aslinya, ataukah kalangan yang menyingkap sumber-sumber asli dengan pemahaman, analisis dan kritik". 36

Dengan demikian, kritik atas otoritas agama menjadi sebuah kewajiban dengan cara menggali sisi esensial, humanis, dan epistemik, serta menyingkap sisi historis (temporal), rasial, dan ideologis menuju hadlârah al-nash yang sempurna, dengan kerangka pikir utamanya adalah proses dialektika manusia dengan realitas sosial, ekonomi, politik dan budaya di satu sisi, dan proses dialog kreatif yang terjalin dengan teks di sisi yang lain. ${ }^{37}$

Pandangan di atas secara tidak langsung telah mematahkan asumsi publik tentang al-Qur'an sebagai Kalam Allah yang diwahyukan sebagai proses komunikasi yang bersifat verbalistikakustik semata tanpa memperbincangakan lagi persoalan ontologis, epistemologis dan aksiologis yang mengitari proses terbentuknya. Untuk itu, meskipun terjadi problem jarak ontologis antara keberadaan Muhammad dalam memunculkan sisi epistemologisnya yang bersifat natural dengan Tuhan yang bersifat supranatural, maka al-Qur'an dan proses pewahyuan haruslah sama-sama memiliki sejarah kontekstualnya. Di mana analisis konteks cukup berperan penting dalam memahami peristiwa pewahyuan, sebab konsep wahyu tidak akan dapat dimengerti kecuali dengan melihat konteks sebelumnya. Hal ini menandakan terdapat hubungan antara realitas (sebagai konteks) dengan teks. Seseorang tidak akan mungkin

\footnotetext{
36 Nasr Hâmid Abû Zaîd, al-Tafkîr fî̀ Zamân al-Takfîr: Dhid al-Jahl wa al-Zaif wa alKhurafât, Cet. 2 (Kairo: Maktabah Madbûlî, 1995), 125-126.

37 Ahmad Rajafi, "Islam dan Kearifan Lokal: Pembaruan Hukum Keluarga di Indonesia Model Inkulturasi Wahyu dan Budaya Lokal", Akademika: Jurnal Pemikiran Islam, 21 \& 1 (2016), 73.
} 
mengerti dan dapat memahami dengan hanya mengambil teks di luar realitas. 38

Adapun dalil yang perlu direinterpretasi adalah Q.S. al-Nisâ' 4:34, ayat yang seringkali digunakan dalam menjelaskan tentang peran dan tugas penafkahan dalam keluarga; "Kaum laki-laki itu adalah pemimpin bagi kaum wanita, oleh karena Allah telah melebihkan sebahagian mereka (laki-laki) atas sebahagian yang lain (wanita), dan karena mereka (laki-laki) telah menafkahkan sebagian dari harta mereka...".

Ketika menjelaskan tentang ayat di atas, Husein Muhammad pimpinan Pesantren Darut Tawhid Arjawinangun memberikan penegasan bahwa ayat tersebut bersifat informatif, bukan normatif, ${ }^{39}$ dan menginformasikan hubungan gender (hubungan suami-istri) pada saat pewahyuan. Hubungan gender ini pada saat pewahyuan dengan saat ini tentunya ada yang memiliki kesamaan atau pula berbeda. Sehingga dalam konteks saat ini, pria dan wanita bisa menjadi pasangan sejajar atau bahkan wanita bisa menjadi pemimpin atas pria. ${ }^{40}$

Asghar Ali Engineer dengan bahasa dan istilah yang lain menjelaskan bahwa menurutnya Q.S. al-Nisâ' 4: 34 adalah ayat tentang kajian sosial, bukan ayat dalam kajian teologis; atau mengenai ayat yang harus dikaji secara kontekstual bukan secara normatif. Maksud dari ayat sosiologis adalah, bahwa ayat tersebut mendeskripsikan tentang relasi gender (hubungan suami-istri) ketika ayat tersebut diturunkan dan tentunya memiliki kesamaan atau perbedaan dengan konteks saat ini. Sedangkan ayat teologis berarti ayat tersebut bersifat normatif yang harus diterapkan pada semua umat Islam dimanapun dan kapanpun. Dengan demikian ayat tersebut mencerminkan situasi sosial pada saat pewahyuan, yang menurutnya laki-laki menjadi qawwam tapi bukan dalam perspektif hukum. ${ }^{41}$

\footnotetext{
38 Hilman Latief, Nasr Hamid Abu Zaid: Kritik Teks Keagamaan (Yogyakarta: eLSAQ Press, 2003), 30.

${ }^{39}$ Lihat Husein Muhammad, Ijtihad Kyai Husein: Upaya Membangun Keadilan Gender (Jakarta: Rahima, 2011)

${ }^{40}$ Nina Nurmila, "Indonesian Muslim's Discourse of Husband-Wife Relationship", AlJami'ah: Journal of Islamic Studies, 51 \& 1 (2013), 70.

${ }^{41}$ Lihat Asghar Ali Engineer, The Rights of Women in Islam (London: C. Hurst \& co.,1992), 45-46.
} 
Nasr Hâmid Abû Zaid juga memberikan perspektif baru terhadap ayat tersebut, di mana menurutnya Q.S. al-Nisâ' 4:34 bersifat deskriptif, bukan preskriptif. Ini berarti bahwa ayat tersebut telah menggambarkan hubungan gender pada saat pewahyuannya, dan bukan ayat yang secara khusus mengatur hubungan gender untuk kaum muslimin tanpa memperhatikan ruang dan waktu. 42

Adapun secara historis, ayat tersebut pada dasarnya turun untuk menjawab komentar kaum wanita yang diwakili oleh Ummu Salamah tentang bagian laki-laki yang lebih besar dalam pembagian harta waris, sehingga jawaban ayat tersebut memberi arahan psikologis bahwa apa yang dipikirkan oleh para wanita tersebut tidaklah betul, karena sosio-kultur yang hidup pada bangsa Arab saat itu adalah, laki-laki menjadi patron dalam kelurga dan ia memiliki kewajiban untuk mengeluarkan mahar ketika akan menikah dan memberi nafkah setelah akad nikah.

Atas dasar patronasi itulah lalu dalam sighat ijab dan kabul ${ }^{43}$ penyerahan hak dan kewajiban dilakukan oleh wali (ayah dari mempelai wanita) ke mempelai laki-laki dengan kalimat ankahtuka (aku nikahkan engkau), bukan dengan kalimat "aku nikahkan anakku kepadamu". Dengan kalimat itulah maka laki-laki (suami) memiliki kewajiban untuk menjaga, mengurus dan memberi nafkah secara mutlak bagi istrinya.

Keterangan tersebut menunjukkan bahwa dalam menjalankan komunikasi, Allah SWT menggunakan jalan taghyîr, yakni penerimaan Allah SWT atas perilaku sosial bangsa Arab yang menjadikan laki-laki sebagai patron namun perlu direvisi dengan memberikan ruang kepada wanita dengan cara mendapatkan keuntungan mahar dan nafkah. Psikologi yang muncul dalam komunikasi antara Tuhan (Allah SWT) dengan hamba-Nya (melalui Muhammad saw) inilah yang perlu diimplementasikan dalam konteks psikologi sosial umat Islam di Nusantara.

42 Nasr Hâmid Abû Zaid, "The Nexus of Theory and Practice", dalam The New Voices of Islam: Rethinking Politics and Modernity (Berkeley and Los Angeles: University of California Press, 2006), 163-164.

43 Ijab adalah lafaz yang diucapkan oleh wali atau wakilnya. Sedangkan qabul adalah lafaz yang diucapkan oleh calon suami atau wakilnya. Lihat Ibrahim Hosen, Figh Perbandingan Masalah Pernikahan Jilid 1 (Jakarta: Pustaka Firdaus, 2003), 153. 
Psikologi sosial yang lahir pada bangsa Arab saat itu tentunya berbeda dengan psikologi sosial umat Islam di Nusantara. Umat Islam di Nusantara memiliki tiga bentuk kekerabatan yakni patrilineal, matrilineal, dan bilateral. ${ }^{4} \mathrm{Hal}$ ini berbeda dengan bangsa Arab yang hanya memiliki satu sistem kekerabatan saja yakni patrilineal. Dengan kemajemukan sistem kekerabatan tersebut maka pola pemikirannya juga lebih kompleks.

Sebagai contoh, umat Islam di Padang memegang tegung semboyan adat basandi syara', syara' basandi kitabullah, yakni adat harus sejalan dengan hukum syari'at dan hukum syari'at itu sumbernya adalah al-Qur'an, namun dalam tataran implementatif, umat Islam Padang masih memegang teguh sistem kekerabatan matrilineal dalam keluarga dan bukan patrilineal, sehingga dalam pembagian waris anak perempuan mendapat lebih besar dari anak laki-laki.

Atas dasar nalarisasi tersebut, maka apakah Allah SWT sebagai Tuhan bersifat kaku dan tidak fleksibel dalam berkomunikasi dengan hamba-Nya pada konteks nafkah tersebut? Tentu jawabannya adalah tidak, karena Allah SWT adalah Sang Maha Kuasa, dan dalam membentuk syariat-Nya yang lahir dari budaya lama, dilakukan melalui tiga jalan, yakni tahmîl (menerima secara utuh budaya lama tersebut), taghyîr (menerima dengan melakukan perbaikan-perbaikan di dalamnya), dan tahrim (menolak secara penuh budaya tersebut sebagai hukum). ${ }^{45}$

Rasionaliasi atas implikasi teoritis tersebut adalah, bahwa hukum-hukum di dalam nash al-syari'ah termasuk hukum keluarga yang bersumber dari budaya lokal dengan konsekwensi tahmîl, tahrîm atau taghyîr, maka ketika masuk ke dalam konsekuensi taghyîr maka proses transformasi tidak berhenti di masa nabi saja namun terus berlangsung sesuai kehendak zaman yang mampu merubah budaya

44 Patrilineal merupakan bentuk kekerabatan yang menarik garis nasab hanya melalui jalur bapak atau laki-laki. Matrilineal merupakan bentuk kekerabatan yang menarik garis nasab melalui jalur ibu atau perempuan semata. Sementara bilateral merupakan bentuk kekerabatan yang menentukan garis nasab melalui jalur bapak dan ibu. Lihat Hazairin, Hukum Kewarisan Bilateral Menurut Al Quran dan Hadits (Jakarta: Tintamas,1990), 9-12; Amir Syarifuddin, Pembaharuan Pemikiran Dalam Hukum Islam (Padang: Angkasa Raya, 1993), 144.

45 Ahmad Rajafi, Inkulturasi Wahyu dan Budaya Lokal Serta Implikasinya Terhadap Pembaharuan Hukum Keluarga di Indonesia, Disertasi (Lampung: IAIN Raden Intan, 2015), 22. 
tersebut dengan konsep nalar minor menuju nalar mayor. Rumusannya sama dengan konsep al-tadarruj fi al-hukm, yakni menerapkan hukum secara berangsung-angsur, di mana antara ayat yang satu dengan ayat yang lain di dalam al-Qur'an memiliki keterikatan yang kuat dalam memberi pemahaman atas maksud Tuhan dalam menurunkan hukumnya di dunia ini, plus konsep annaskh yang menghapus aturan hukum yang lama karena adanya aturan baru yang diturunkan Allah.

Pembacaan terhadap ayat dalam konteks nafkah ini, untuk dikontekstualisasikan dengan keadaan Islam Nusantara harus dilandasi pada konsep taghyîr. Budaya umat Islam di Nusantara memberi peluang yang sama antara laki-laki dan wanita. Wanitawanita banyak yang membantu ekonomi keluarga dengan turut bekerja di luar rumah, atau bahkan menjadi ujung tombak keluarga dalam mencari nafkah dan bahkan bertukar tempat dengan suaminya. Pekerjaan kasarpun banyak yang dilakoni oleh para perempuan di era ini, seperti menarik becak atau menjadi supir taxi, ojek, dan terdapat di beberapa daerah sebuah tradisi yang menjadikan perempuan berperan aktif sebagai pencari nafkah sedangkan suaminya berperan pasif.

Amir Syarifuddin secara spesifik juga telah memberikan sebuah statemen hukum, di mana kewajiban memberikan nafkah oleh suami kepada istrinya yang berlaku dalam fiqh didasarkan kepada prinsip pemisahan harta suami dan istri. Prinsip ini mengikuti alur pikir bahwa suami itu adalah pencari rezeki; rezeki yang diperolehnya itu menjadi haknya secara penuh dan untuk selanjutnya suami berkedudukan sebagai pemberi nafaqah. Sebaliknya istri bukan pencari rezeki dan untuk memenuhi keperluannya ia berkedudukan sebagai penerima nafaqah. Oleh karena itu, kewajiban nafaqah tidak relevan dalam komunitas yang mengikuti prinsip penggabungan harta dalam rumah tangga, ${ }^{46}$ termasuk di Indonesia yang memiliki kebebasan mencari nafkah dari masing-masing pasangan suami dan istri dan kemudian menggabungkan penghasilan bersamanya. Hal ini diatur di dalam Undang-undang Nomor 1 Tahun 1974 tentang Perkawinan, Pasal 35 ayat (1), di mana; Harta benda yang diperoleh selama perkawinan menjadi harta bersama.

${ }^{46}$ Amir Syarifuddin, Pembaharuan..., 165-166. 
Berdasarkan penggunaan teori holistik dan equal partner dalam memahami ketentuan nas\}s \} dan KHI, pemikiran yang dituju penulis mengarah pada pola hubungan yang berkeadilan dan kesejajaran suami isteri. Pertama, hubungan yang berkeadilan antara suami isteri mengandung maksud bahwa peranan masing-masing suami isteri dalam keluarga disesuaikan dengan kapasitas kemampuan yang dimiliki dan peranan social yang dimainkan. Suami mempunyai tanggung jawab memenuhi nafkah adalah karena peranan yang dimiliki dan realitas sosial. Konstruksi budaya dalam masyarakat kita telah membedakan antara pekerjaan laki-laki dan perempuan. Laki-laki dikonstruksikan untuk bekerja di sektor publik dan produktif, sedangkan perempuan dikonstruksikan untuk bekerja di sector domestik dan reproduktif. 47

Mengenai hal ini, maka perlu diteliti kembali kelanjutan dari ayat tentang nafkah tersebut, di mana pembacaan terhadap ayat tidak boleh terputus pada masalah qawâm (kepemimpinan) dan bimâ anfaqû min amwâlihim (penafkahan suami kepada istri) saja, akan tetapi harus terus diselesaikan hingga akhir ayat tersebut, di mana Allah menjelaskan; "...Kemudian jika mereka (istri-istri) mentaatimu, maka janganlah kamu mencari-cari jalan untuk menyusahkannya. Sesungguhnya Allah Maha Tinggi lagi Maha Besar."

Kata kunci pada ayat tersebut adalah falâ tabghî 'alaihinna sabîlâ, yakni janganlah kamu mencari-cari jalan untuk menyusahkannya (istri-istri). Artinya, ketaatan pasangan terhadap pasangannya adalah ketika bersinergi hubungan kemitraan antara keduanya, dan suami harus memberikan fasilitas yang optimal bagi istri, sehingga istri tidak akan tergelincir pada perbuatan yang dianggap durhaka kepada suami.

Interpretasi tersebut tentunya belum optimal dalam menjawab problem umat secara holistik, karena masih terlihat "tidak ramah gender". Oleh karennya, reinterpretasi melalui pendekatan historis atas penghormatan Islam terhadap perempuan melalui firman-firman Allah tersebut sangat diperlukan, di mana penafsiran terhadap ayatayat al-Qur'an tidak boleh bersifat stagnan, namun harus terus

47 Syuhada, "Analisis Tentang Konsekuensi Harta Bersama Terhadap Kewajiban Suami Memberi Nafkah dalam KHI", Tafaqquh, 1 \& 1 (2013), h. 57-58. 
berdealektika sesuai dengan perubahan zaman, tempat dan keadaan, termasuk di Indonesia.

Pemahaman terhadap peran serta perempuan pada ranah publik (nafkah) di era awal turunnya ayat tentu berlaku minor, namun sesuai perkembangan zaman ia akan dapat berlaku mayor dengan pemberian hak yang sama antara laki-laki dan perempuan dalam tugas penafkahan. Perubahan dari nalar minor menuju nalar mayor terlihat dari sejarah keberadaan perempuan di dunia, di mana pada awalnya perempuan itu tidak ada karena Tuhan hanya mengadakan Adam sebagai sosok laki-laki, lalu diadakan (Hawa) sebagai teman setia Adam dengan sifat minor karena semua kendali masih berada pada "tangan" Adam.

Saat Islam datang, perempuan mendapat tempat di dalam Islam dengan hak-hak penuh atas dirinya (tidak lagi menjadi seperti barang dagangan dan harta waris keluarga) seperti hak suara dalam menerima atau menolak calon suaminya, mendapat harta mahar dan bahkan juga mendapat bagian dalam kewarisan. Meskipun demikian, sifat nalar keberadaan perempuaan dalam hukum dan masyarakat pada masa awal Islam masih bersifat minor namun bergerak menuju nalar mayor.

Pergerakan nalar mayor baru dapat terlihat ketika Islam berekspansi ke luar dari tanah Arab, seperti ke Nusantara, dan berinteraksi dengan budaya lokal yang hidup di dalam masyarakat dan tentunya berbeda dengan budaya hukum yang hidup di ArabIslam. Pada konteks Nusantara yang merupakan wilayah besar dan multikultur tentu berbeda dengan sosio-kultur Arab, jika di Arab hanya memiliki satu sistem kekerabatan yakni patrilineal, maka di Nusantara terdapat tiga sistem kekerabatan yang terjalin harmoni positif dengan Islam. Oleh karenanya, pada konteks nafkah perspektif Islam Nusantara, harus berbasis kemitraan yang tidak dirinci secara matematis bentuk dan pembagiannya, namun dikeluarkan atas dasar kebutuhan bersama.

Konsepsi tersebut selaras dengan hadits Rasûlullâh yang menceritakan tentang Asma' binti Abu Bakar yang selalu membantu suaminya dalam mencukupi perekonomian keluarganya. Dalam hadits tersebut dijelaskan bahwa ketika Zubair menikahi Asma', ia tidak memiliki apa-apa kecuali kuda. Maka Asma' ikut membantu suami merawatnya dengan cara memberi rumput dan mengurus 
kudanya. Bahkan dalam pekerjaan lainnya, Asma' sering kali menjunjung buah kurma dari kebun yang dijatahkan Rasulullah saw pada Zubair, dan jauh kebun tersebut adalah dua pertiga farsakh. 48 Pada suatu hari ia pernah bertemu dengan Rasulullah dan beberapa sahabatnya. Rasulullah merasa iba dan memanggilnya. Namun ketika Rasulullah mengajak Asma' untuk menaiki untanya, Asma' menolaknya dengan halus. ${ }^{49}$

Konsepsi di atas juga sejalan dengan ayat kedua yang biasa digunakan sebagai dalil tentang nafkah, yakni Q.S. al-Thalaq 65: 7 dengan menegaskan kewajiban memberi nafkah dengan kata kunci $d z \hat{u}$ sa'atin min sa'atih (orang yang mampu memberi nafkah menurut kemampuannya). Meskipun para ulama sepakat bahwa konteks ayat tersebut adalah tentang kewajiban nafkah pasca perceraian, ${ }^{50}$ namun psikologi yang muncul ketika ayat tersebut turun adalah, adanya jawaban hukum atas keberadaan wanita pasca perceraian, yang tidak boleh diperlakukan "habis manis sepah dibuang", akan tetapi ada tanggungjawab dari mantan suami untuk tetap memberi nafkah kepadanya.

Konsep psikologis seperti ini tentu sebagai petunjuk kepada para wanita bahwa zaman akan terus berubah dan wanita harus bergerak maju dalam membangun kemandirian ekonomi mereka, tidak boleh hanya berpangku tangan pada suaminya, sehingga apa yang diusahakan mampu memberi dampak positif bagi dirinya dan orang-orang disekelilingnya. Mafhûm mukhâlafah-nya (makna tersirat), jika wanita tersebut ditinggal cerai oleh suaminya, baik cerai talak ataupun cerai mati, maka wanita (istri) masih dapat meneruskan kehidupan keluarganya melalui kemandirian ekonomi yang dimilikinya.

Nalar seperti ini juga dikuatkan oleh hadits tentang istri Abû Sufyân yang diperbolehkan untuk mengambil simpanan suaminya karena sifat pelit suaminya. Psikologi yang terbangun dari hadits tersebut juga sejalan dengan psikologi dalam Q.S. al-Thalâq 65:7.

48 Ukuran satu farsakh kurang lebih delapan kilometer, lihat Pusat Bahasa, Kamus Bahasa Indonesia..., 404.

${ }^{49}$ Lihat Muhammad bin Isma'il Abu Abdillah al-Bukhari al-Ja'fi, al-Jami' al-Shahih alMukhtashar (Beirut: Dar ibn Katsir, 1987), V, 2002.

50 Lihat Abû al-Fidâ' Ismâ'îl bin Umar bin Katsîr al-Qurasyî al-Damsiqî, Tafsîr alQur'ân al-'Azhîm (Damaskus: Dâr Thayyibah, 1999), VIII, 152. 
Artinya, seorang istri selama dapat sejalan dan seirama dalam rumahtangga dengan suaminya dalam bentuk komunikasi yang baik menuju kemufakatan ekonomi keluarga, maka istri seyogyanya dapat membangun ekonominya secara mandiri sebagai bagian kontribusi ekonomi rumahtangga, sekaligus mempersiapkan segala kemungkinan duniawi yang akan dihadapinya di masa depan.

Kemufakatan ekonomi keluarga adalah rumusan atau konsep yang tidak lagi memberi peluang di dalam rumahtangga sebuah adagium "keluarga berbasis harta", akan tetapi yang harus lahir adalah "keluarga berbasis kepercayaan", di mana kepercayaan menyelimuti seluruh lingkup rumahtangga, istri boleh saja bekerja di luar rumah bahkan sebagai pemberi nafkah utama dalam rumah tangga yang bertukar tempat dengan suaminya, karena syarat utama yang ditunjukkan oleh Allah SWT adalah; "...wanita yang saleh, ialah yang taat kepada Allah lagi memelihara diri ketika suaminya tidak ada, oleh karena Allah telah memelihara (mereka)..." (Q.S. al-Nisâ' 4:34).

Ayat tersebut meskipun ditujukan kepada wanita (istri) secara eksplisit, namun mafhûm (pemahaman) di dalamnya dapat berarti umum dengan diarahkan pada arti "pasangan". Dengan demikian penggalan ayat tersebut dapat berarti, pasangan yang baik adalah pasangan yang taat kepada Allah dan mampu menjaga dirinya dari hal-hal yang dapat membuatnya terjerumus ke dalam jurang kenistaan meskipun pasangannya tidak sedang berada bersama dirinya. Tidak laki-laki (suami) ataupun wanita (istri), semuanya dapat saja tergoda dengan uang, harta, tahta, laki-laki yang tampan, wanita yang cantik, dan lain sebagainya. Untuk itu, ketaatan kepada Allah dalam bentuk menjaga amanah keluarga (kepercayaan) adalah kata kunci yang ditegaskan dalam ayat tersebut.

\section{Kesimpulan}

Islam adalah agama yang membawa rahmat bagi semesta alam termasuk bagi anak manusia. Pernikahan yang dijalankan oleh setiap anak manusia tentunya diarahkan untuk turut mendapatkan rahmat Allah SWT tersebut. Untuk itulah Allah mengajarkan agar dapat menjaga pasangan dan anggota keluarga dengan membangun kesejahteraan keluarga melalui jalan ekonomi. Ayat tentang nafkah yang direinterprtasi melalui pendekatan Islam Nusantara dengan model teori inkulturasi wahyu dan budaya lokal mampu 
mengapresiasi perkembangan zaman sehingga nafkah yang merupakan bagian dari ekonomi keluarga tidak lagi ditarik pada garis patrilineal akan tetapi dapat juga berbasis bilateral dengan konsep "kemufakatan ekonomi keluarga", dengan artian bahwa wanita (istri) dapat ikut serta dalam membantu ekonomi keluarga secara makro atau bahkan sebagai pemberi nafkah utama dalam rumah tangga yang bertukar tempat dengan suaminya dengan syarat ketaatan kepada Allah SWT dalam bentuk menjaga amanah keluarga atau kepercayaan.

\section{Daftar Pustaka}

Anshârî, Zakariyyâ al-. Fath al-Wahhâb, Beirût: Dâr al-Kutub al'Ilmiyyah, $1418 \mathrm{H}$

Nisâbûrî, Abû al-Husein Muslim bin al-Hajjâj bin Muslim al-Qusyairî al-. al-Jâmi' al-Shahîh al-Musammâ Shahîh Muslim, Beirût: Dâr alAfâq al-Jadîdah, t.t.

Bahri, Syamsul. "Konsep Nafkah dalam Hukum Islam", Kanun Jurnal Ilmu Hukum, 66 \& 18, 2015.

Dimyathî, Abû Bakr bin Sayyid Muhammad Syathâ al-. I'ânah alThâlibîn, Beirût: Dâr al-Fikr, t.t.

Engineer, Asghar Ali. The Rights of Women in Islam, London: C. Hurst \& co., 1992.

Hashfakî al-, al-Dur al-Mukhtâr, Beirût: Dâr al-Fikr, 1386 H

Haqqî, Ismâ'îl. Tafsir Rûh al-Bayân, Beirût: Dâr Ihyâ' at-Turâts al'Arabi, t.t.

Hazairin, Hukum Kewarisan Bilateral Menurut Al Quran dan Hadits, Jakarta: Tintamas, 1990.

Hosen, Ibrahim. Figh Perbandingan Masalah Pernikahan Jilid 1, Jakarta: Pustaka Firdaus, 2003.

Hudaya, Hairul. "Hak Nafkah Isteri (Perspektif Hadis dan Kompilasi Hukum Islam)", Mu'adalah Jurnal Studi Gender dan Anak, 1 \& 1, 2013.

Ibn Katsîr, Abû al-Fidâ' Ismâ'îl Ibn Umar. Tafsîr al-Qur'ân al-'Azhîm, Damaskus: Dâr Thayyibah, 1999.

Jazirî, Abd ar-Rahmân al-. al-Fiqh 'alâ al-Madzâhib al-'Arba'ah, Beirût: Dâr al-Fikr, 1996. 
Kamrava, Mehran, (ed.). The New Voices of Islam: Rethinking Politics and Modernity, Berkeley and Los Angeles: University of California Press, 2006.

Khalâf, Abd al-Wahâb. Ahkâm al-Ahwâl al-Syakhshiyyah fî̀ al-Syarî'ah alIslâmiyyah, cet. 2, Kuwait: Dâr al-Qalam, 1990.

Latief, Hilman. Nasr Hamid Abu Zaid: Kritik Teks Keagamaan, Yogyakarta: eLSAQ Press, 2003.

Ma'luf, Louis. al-Munjid, Beirut: al-Syirkiyah, 1986.

Abû al-Qâsim al-Husain bin Muhammad. al-Mufradat fi Gharîb alQur'an, Beirut: Dar al-Fikr, t.th.

Muhammad, Husein. Ijtihad Kyai Husein: Upaya Membangun Keadilan Gender, Jakarta: Rahima, 2011.

Munawwir, Ahmad Warson. Al-Munawwir Kamus Arab-Indonesia, Yogyakarta: Pondok Pesantren Al-Munawwir, 1984.

Nasution, Khoiruddin. Islam Tentang Relasi Suami dan Istri (Hukum Perkawinan I) Dilengkapi Perbandingan Undang-undang Negara Muslim, Yogyakarta: Tazzafa Academia, 2004.

Nelli, Jumni. "Analisis Tentang Kewajiban Nafkah Keluarga dalam Pemberlakuan Harta Bersama", Al-Istinbath: Jurnal Hukum Islam, $2 \& 1,2017$.

Nurmila, Nina. "Indonesian Muslim's Discourse of Husband-Wife Relationship", Al-Jami'ah: Journal of Islamic Studies, 51 \& 1, 2013

Nurnazli, "Nafkah dalam Pendekatan Interdisipliner", Asas Jurnal Hukum dan Ekonomi Islam, 5 \& 2, 2013.

Pusat Bahasa, Kamus Bahasa Indonesia, Jakarta: Departemen Pendidikan Nasional, 2008.

Qurthûbî, Abû Abdillâh Muhammad bin Ahmad al-Anshârî al-. alJâmi' li Ahkâm al-Qur'ân, Kairo: Dâr al-Hadîts, 2002.

Râfi'î, Sâlim bin Abd al-Ghanî al-. Ahkâm al-Ahwâl al-Syakhshiyyah li alMuslimîn fi al-Gharb, Beirût: Dâr Ibn Hazm, 2002.

Rajafi, Ahmad. "Islam dan Kearifan Lokal: Pembaruan Hukum Keluarga di Indonesia Model Inkulturasi Wahyu dan Budaya Lokal", Akademika: Jurnal Pemikiran Islam, 21 \& 1, 2016

--------, Inkulturasi Wahyu dan Budaya Lokal Serta Implikasinya Terhadap Pembaharuan Hukum Keluarga di Indonesia, Disertasi, Lampung: IAIN Raden Intan, 2015. 
--------, dan Yudistiawan, Rahmat. "Kewarisan Produktif: Meramu Makna Adil Melalui Waris Produktif", Al-Risalah: Forum Kajian Hukum dan Sosial Kemasyarakatan, 16 \& 2, 2016.

Rozali, Ibnu. "Konsep Memberi Nafkah Bagi Keluarga dalam Islam", Intelektualita, 6 \& 2, 2017

Sâbiq, Sayyid. Fiqh al-Sunnah, Kairo: Dâr al-Fikr, 2002.

Shihab, M. Quraish. Wawasan Al-Qur'an: Tafsir Maudhu'i atas Pelbagai Persoalan Umat, Bandung: Mizan, 1996.

Sa'dî, Abd ar-Rahmân bin Nâshir al-. Taisîr al-Karîm al-Rahmân fi Tafsîr Kalâm al-Mannân, Alih Bahasa oleh Muhammad Iqbal, at al., Tafsir Al-Qur'an Surat An-Nisâ' - al-An'am, cet. 6, Jakarta: Darul Haq, 2015.

Subaidi, "Konsep Nafkah Menurut Hukum Perkawinan Islam", Isti'dal: Jurnal Studi Hukum Islam, 1 \& 2, 2014.

Syarifuddin, Amir. Pembaharuan Pemikiran Dalam Hukum Islam, Padang: Angkasa Raya, 1993.

Syuhada, "Analisis Tentang Konsekuensi Harta Bersama Terhadap Kewajiban Suami Memberi Nafkah dalam KHI", Tafaqquh, 1 \& 1, 2013.

Zuhailî, Wahbah al-. al-Figh al-Islâmî wa Adillatuh, Suriah: Dâr al-Fikr, 2002.

Zaîd, Nasr Hâmid Abû. al-Tafkîr fî Zamân al-Takfîr: Dlid al-Jahl wa alZaif wa al-Khurafât, Cet. 2, Kairo: Maktabah Madbûlî, 1995. 